\title{
Lektura deiktyczna. Rozważania o dyskursie miłości oraz poetyce interpretacji
}

\begin{abstract}
Mastalski Arkadiusz Sylwester, Lektura deiktyczna. Rozważania o dyskursie miłości oraz poetyce interpretacji [Deictic reading: reflections on the discourse of love and the poetics of interpretation]. "Przestrzenie Teorii” 22. Poznań 2014, Adam Mickiewicz University Press, pp. 39-54. ISBN 978-83-232-2827-1. ISSN 1644-6763.

This article analyzes confessions of love from the perspective of communication - it shows the paradoxical character of such confessions and the disparity between this and other models of communication. By referring to the writings of Roland Barthes, Ludwig Wittgenstein, and Jacques Derrida as well as papers dealing with cognitive linguistics and cognitive poetics, the article presents the interpretative consequences of deictic shifts (shifts in textual perspectives).
\end{abstract}

Never seek to tell thy love Love that never told can be

- William Blake ${ }^{1}$

\section{Wyznanie miłosne jako sytuacja komunikacyjna}

Zawarta w zacytowanym fragmencie wiersza Williama Blake'a wątpliwość jest (co chyba oczywiste) pozorna. Gdy więc pytamy, czy miłość można wyznać (lub też jej nie wyznawać), nie o to, rzecz jasna, idzie, czy jest ona komunikowalna czy niekomunikowalna w sensie ścisłym (z własnego, jednostkowego doświadczenia wiemy przecież, że w niektórych momentach życia jest to nie tylko możliwe, ale wręcz nieuchronne, w innych zaś - zaistnieć nie ma prawa). Miłosna deklaracja jest więc w danej, określonej sytuacji komunikacyjnej, której uczestnikami są dwa podmioty ludzkie uwikłane $\mathrm{w}$ ów specyficzny dyskurs, niezbędna (a zatem w nieusuwalny sposób daje się również wyrazić: w cytowanym wierszu twórca Zaślubin nieba i piekła doda więc po kilku zaledwie wersach: „I told my love, I told my love, / I told her all my heart"2), gdy zaś odpowiednie okoliczności nie występują, jako wyznanie staje się bezsensowna i wyartyku-

${ }^{1}$ Kocham - nie próbuj powiedzieć; Miłości słowem nie wyznasz [tłumaczenie własne A.S.M.]. W. Blake, Never seek to tell thy Love, [w:] The Selected Poems of William Blake, London 1994, s. 94.

${ }^{2}$ Lecz jednak wyznałem, wyznałem! Swa miłość sercem całym [tłumaczenie własne A.S.M.]. Tamże. 
łowana być nie może. W każdym jednak wypadku owa artykulacja ma charakter specyficzny, by nie powiedzieć - swoiście paradoksalny. Po pierwsze więc, paradoks miłosnej komunikacji polega na tym, że wyznanie to, będąc komunikowalnym (choć w znacznie ograniczonym stopniu) w sensie dyskursywnym, zawsze pozostaje jednak poza granicami systemu społecznej wymiany znaków, jest znakiem jego wewnętrznej aporii, nieustannym naruszaniem zasad dystrybucji sensu i działaniem transgresywnym, które: „podważa modelowość komunikacji”3:

Zakochani wiedzą - napisze Rafał Nahirny - i wyznanie miłosne potrzebne jest do ukonstytuowania ich wzajemnej relacji. Muszą jednak wypracować własny system znaków i oznak miłości, doprecyzować i dookreślić język, którym posługują się w celu zbudowania wspólnego związku. [...] gra [językowa - A.S.M.] otwierana przez wyznanie miłosne jest wyraźnie zorientowana na siebie samą [...], [a jej specyfika] polega właśnie na tym, i spełnia się ona w ustalaniu własnych wzorców ${ }^{4}$.

Komunikacja miłosna jest więc trochę niczym mit w rozumieniu Rolanda Barthesa: zawłaszcza znak, jego signifiant i signifié, by następnie uczynić z nich nowy element znaczący, w odmiennej już strukturze, o innej jednakże semantyce ${ }^{5}$. Podobnie czyni miłości, gdy pozbawia słowa i gesty znaczeń symbolicznych, podstawiając w ich miejsce odmienne, subiektywne i jednorazowe sensy (których ludzie pozostający poza tą jedną, niepowtarzalną relacją nie są w stanie pojąć). Ta samozwrotność miłosnej komunikacji wiąże się z jej, jak to określa autor Imperium znaków, „wędrującym” (zależnym od użycia, pozbawionym jednego zastosowania) ${ }^{6}$, a także performatywnym (w sensie Austinowskim, jako akt mowy: formuła „kocham cię” nie istnieje, jeśli nie jest wypowiedziana, natomiast w momencie artykulacji ustanawia nową odmienną rzeczywistośćc) cha-

${ }^{3}$ A. Burzyńska, Literatura, komunikacja, miłość, [w:] Polonistyka w przebudowie. Literaturoznawstwo - wiedza o języku - wiedza o kulturze - edukacja. Zjazd Polonistów, Kraków 22-25 września 2004, red. M. Czermińska, t. II, Kraków 2005, s. 657. Niklas Luhmann powiada tu, iż: „kto jest wierny regułom, nie jest wierny ukochanej”, [w:] tegoż, Semantyka miłości, przeł. J. Łoziński, Warszawa 2003, s. 84; cyt. za: R. Nahirny, „Wszyscy mówia kocham-cię. Analiza wyznania miłosnego, „Teksty Drugie” 2007, nr 1-2, s. 264. Por. Platon, Uczta, [w:] tegoż, Dialogi, w przekładach W. Witwickiego, wybrał, tekst przejrzał, przedmową i objaśnieniami opatrzył A. Lam, Warszawa 2007, s. 83.

${ }_{4}^{4}$ R. Nahirny, dz. cyt., s. 265-266. Autor, mówiąc o grze, ma oczywiście na myśli takie znaczenie terminu, jakie nadał mu Ludwig Wittgenstein. Zob. tegoż, Dociekania filozoficzne, przeł. B. Wolniewicz, Warszawa 2000, s. 20.

5 Por. R. Barthes, Mit dzisiaj, [w:] tegoż, Mitologie, przeł. A. Dziadek, Warszawa 2008, s. 241-248.

${ }^{6}$ R. Nahirny, dz. cyt., s. 263.

${ }^{7}$ Zob. J.L. Austin Mówienie i poznawanie, przeł. B. Chwedeńczuk, Warszawa 1993. 
rakterem. Relacja taka może zostać ustanowiona tylko i wyłącznie jako zupełnie swoiste doświadczenie, które nie jest przekładalne ani na inny system czy zestaw znaków (nie można powiedzieć „kocham”, używając innego zwrotu), ani też na odmienną od siebie samej sytuację komunikacyjną (nie można wyznać tego nikomu innemu, replikacji podlega forma komunikatu, nie zaś jego treść) 8 , a zatem:

ustanawia się tylko w jednej jedynej sytuacji, która zawsze pragnie być pierwszą i jedyną we wszechświecie. Miłosna interakcja - zauważa Anna Burzyńska - nie ma większego sensu poza relacją tego właśnie nadawcy i tego właśnie odbiorcy miłosnego komunikatu9 9

Nie ma więc również ani (implikowanego strukturalnie czy tylko hipotetycznego) teoretycznego nadawcy, ani też takiego odbiorcy. Wyznanie to nie wykracza nigdy poza hic et nunc jednostkowego, konkretnego aktu komunikowania, a jego charakterystyka determinowana jest nie tylko podmiotowo, ale i temporalnie - przez co rozumiem, że performatywne usankcjonowanie swoistego status quo ma zawsze charakter tylko i wyłącznie momentalny. Już więc na tym etapie rozważań zauważyć można, że dyskurs miłosny ma deiktyczną naturę. Można też chyba powiedzieć, że komunikacja miłosna jest antytezą komunikacji literackiej, ta druga bowiem - na co zwraca uwage Adam Kulawik - jest oderwana od konkretnej sytuacji komunikacyjnej, co oznacza, że tekst może zostać odczytany nie w jednej, a w wielu sytuacjach. Co więcej, do odczytania może w ogóle nie dojść, albowiem odbiorca pozostaje zazwyczaj nieokreślony czy wręcz niepewny ${ }^{10}$. Tak więc Barthes napisze w swych Fragmentach dyskursu miłosnego ${ }^{11}$, iż nie tylko: „Po pierwszym wyznaniu kolejne «kocham cię» nie znaczy już nic" (a zatem jest ono ,jednorazowe”, nieiterowalne), ale również kilka linijek później dopowie: „Kochać nie istnieje w bezokoliczniku”, „nie jest zdaniem, nie przekazuje sensu, lecz trzyma się sytuacji granicznej” oraz (parę stron dalej): „Słowo to (słowo-zdanie) ma sens jedynie w chwili, kiedy je wypowiadam; poza bezpośrednim wy-

$8 \mathrm{~W}$ przypadku, kiedy tekst ten zostanie wyartykułowany non bona fide, będzie sprzeczny z regułą jakości. Zob. P. Grice: Logika i konwersacja. tłum. J. Wajszczuk, „Przegląd Humanistyczny" 1977, z. 6.

${ }^{9}$ A. Burzyńska, dz. cyt., s. 567.

10 A. Kulawik, Poetyka. Wstęp do teorii dzieła literackiego, wyd. 2 poprawione, Kraków 1994, s. 13-14. Por. rozważania o piśmie i nieobecności w pracy Jacques'a Derridy, Pismo i telekomunikacja, „Teksty” 1975, z. 3.

11 Warto zwrócić uwagę na fakt, iż Stanisław Jasionowicz zamiast słowa „dyskurs” używa w tłumaczeniu dzieła Barthesa słowa „rozmowa”, zwracając uwage na komunikacyjny aspekt miłości; zob. tegoż, Roland Barthes - Gilbert Durand. Wizje pluralizmu kultury, Kraków 1999, s. 95. 
powiedzeniem nie ma w nim żadnej informacji, żadnego zasobu, żadnego sensu”, „nie należy [więc - A.S.M.] ani do lingwistyki, ani do semiologii”12.

Co więcej, jak postaram się wykazać niżej, w pewnych sytuacjach aporetyczna natura miłosnej komunikacji prowadzi również do swoistego zatarcia ontologicznej różnicy pomiędzy zaangażowanymi $\mathrm{w}$ proces komunikowania pomiotami (co, w szerszym planie, stanowi przecież aksjomatyczny wyznacznik miłości jako relacji) ${ }^{13}$. Owa dyskursywna nieprzystawalność, nietransparentność i problematyczność aktu wyznania miłosnego jako sytuacji lingwistycznej, to zatarcie granic pomiędzy adresatem i odbiorcą, dobitnie wyrażona zostaje w wierszu Marcina Świetlickiego Nie się, w którym poeta pisze:

Kochać się - to oznacza chyba siebie kochać, więc

kochać należy bez się, kochać to coś w tobie,

co nie jest się, się nie ma, jeśli kochać, wiesz? ${ }^{14}$.

Podając w wątpliwość potoczne rozumienie zaimka zwrotnego „się", którego komunikacyjną intencją jest - co zdaje się z pozoru oczywiste - właśnie wyrażenie dwukierunkowej zwrotności aktu kochania i przesuwając punkt ciężkości wyrażenia na adresata, poeta przekształca wyjściową sytuację dialogową i dokonuje przesunięcia od podmiotowego „się" (siebie) ku odbiorcy wyznania. Celowe zatarcie i przewartościowanie wprowadza dysonans, dekonstruuje pojęcie miłości w znaczeniu, jakie potocznie jest mu nadawane, zabarwia je silnym odcieniem subiektywności. Dlatego właśnie, że wyznanie miłosne nie ma jednej natury, jednego sensu (czy też właśnie ma zawsze jeden sens, ale za każdym razem inny), jest ono w pewien przewrotny sposób niekomunikowalne i nie poddaje się filozoficzno-filologicznemu rozbiorowi, jaki z łatwością radzi sobie nawet ze „zwykłymi” performatywami. Jak zauważa komentujący rozważania autora Mówienia i poznawania Nahirny:

W przykładach, którymi posłużył się John Langshaw Austin, prowadząc swoje skrupulatne badania przedstawione w Jak działać słowami, przejawia się całe bogactwo relacji międzyludzkich: „obrażam cię”, „przepraszam cię”, „witam cię”, „żałuję”, „dziękuję”, „gratuluję”. Pośród wszystkich tych wypowiedzi brakuje chyba tylko jednej, ale jak bardzo ważnej przyzna każdy, kto kiedykolwiek się zakochał. Brakuje „kocham-cię”; tego prostego i banalnego wyznania miłosnego ${ }^{15}$.

12 R. Barthes, Fragmenty dyskursu miłosnego, przeł. M. Bieńczyk, Warszawa 2011. Wyimki pochodzą ze stron 229-232. Jeszcze bardziej poetycko - choć nie mniej trafnie wyrazi tę ostatnią właściwość w jednym z liryków Maria Pawlikowska-Jasnorzewska, pisząc: „Przecież mnie kochasz nad życie? / Sam mówiłeś przeszłego roku...”. Tejże, Miłość, [w:] tejże, Erotyki, wyb. A. Janko, Warszawa 1998, s. 55.

13 Por. Platon, dz. cyt., s. 92.

${ }_{14}$ M. Świetlicki, Nie się, [w:] tegoż, Jeden, Kraków 2013, s. 30.

${ }^{15}$ R. Nahirny, dz. cyt., s. 261. 
Zamieszczone niżej rozważania koncentrują się wobec tego na owej specyficznej relacji komunikacyjnej, jaka ustanowiona zostaje przez to „banalne wyznanie”. Na przykładzie jednego utworu poetyckiego (a właściwie jego nagrania) pokażę mechanizmy, z pomocą których wyrażenia deiktyczne prowadzą do powstania przewartościowań wewnątrz sytuacji komunikacyjnej, a w konsekwencji generują wielowarstwowe odczytania tekstu.

\section{Deiksa w komunikacji literackiej}

Pisząc przed momentem, że sytuacja wyznania miłosnego jest w swej istocie paradoksalna, a przez to odmienna od innych gier językowych, zwróciłem uwage na fakt uczestnictwa w niej podmiotów o wyraziście określonej naturze - jednostkowych, konkretnych i swoistych, wyznanie to implikuje bowiem pojedynczą nieiterowalną instancję nadawczą („Ja”) oraz odbiorczą („Ty”), poza którą nie istnieje. Jak pamiętamy, ma ono również sens tylko w momencie mówienia, czyli w konkretnym „Tu i Teraz". Wszystkie te, pisane przeze mnie wielką literą, wyrażenia mają jak wiadomo jedną wspólną cechę, to znaczy denotują tylko i wyłącznie pewien konkretny (ale zawsze inny) aspekt komunikacji (ja sam stanowie „Ja” tylko dla siebie, zaś każdy inny jest jednocześnie swoim własnym „Ja”; ze względu na osoby i miejsca jest nieskończenie wiele „Teraz”, niemniej określenie to opisuje jedno wybrane punctum na osi czasu i związane z nim przestrzenne locus, o którym mówię). Wyrażenia takie nazywamy

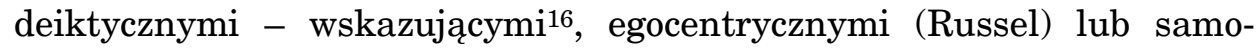
zwrotnymi (Jakobson) ${ }^{17}$, Ich odczytanie zależy od tego, kto, gdzie i kiedy mówi, co w konsekwencji prowadzi do wielości możliwych denotacji ${ }^{18}$.

Przez deiksę rozumiemy lokalizację i identyfikację osoby, obiektu czy zdarzenia, jak też procesu lub działania, które jest przedmiotem wypowiedzi, bądź do którego się ona, ze względu na czasoprzestrzenny kontekst stworzony i podtrzymywany przez akt wypowiedzi i udział w nim [...] jednego nadawcy i co najmniej jednego odbiorcy, odnosi ${ }^{19}$.

16 J. Culler, Teoria literatury. Bardzo krótkie wprowadzenie, przeł. M. Bassaj, Warszawa 1998, s. 43. Por. R. Piętkowa, Tu i teraz. O deiksie w tekście poetyckim, [w:] Semantyka tekstu artystycznego, pod red. A. Pajdzińskiej i R. Tokarskiego, Lublin 2001, s. 149-161.

17 P. Stockwell, Poetyka kognitywna. Wprowadzenie, przekład A. Skucińska, red. naukowa E. Tabakowska, Kraków 2006, s. 64.

18 Por. R. Tsur, Deixis and abstractions. Adventures in space and time, [w:] Cognitive Poetics in Practice, ed. by J. Gavis, G. Steen, London 2003, s. 41.

19 J. Lyons, Deixis, space and time, [w:] Semantics, Vol. II, Cambridge 1977, s. 637; za: D. McIntyre, Point of View in Plays. A cognitive stylistic approach to viewpoint in drama and other text-types, Amsterdam-Philadelphia 2006, s. 92. 
Mówiąc innymi słowy, deiksy jako składniki konceptualizacji w tekście literackim pozwalają czytelnikowi zmieniać punkty widzenia, „wcielać się" w różne role tekstowe i punkty obserwacji poszczególnych postaci lub narratora zlokalizowane na rozmaitych poziomach wypowiedzi, tworzyć i modyfikować konteksty zależnie od momentu (miejsca) wypowiedzi. Tę mentalną zdolność do zmieniania stanowiska poznawczego $\mathrm{w}$ świecie tekstu nazywamy przesunięciem deiktycznym (ang. deictic shift ${ }^{20}$. Doskonałym przykładem wykorzystania deiktycznej struktury w kształtowaniu narracji powieściowej jest początkowa partia Placówki Bolesława Prusa, w której zaangażowanie czytelnika w świat przedstawiony powstaje $\mathrm{w}$ wyniku użycia narracji $\mathrm{w}$ drugiej osobie liczby pojedynczej. Przesuwa ona w niezwykły sposób centrum deiktyczne (deictic center) ku samemu czytelnikowi wcielającemu się bezpośrednio $\mathrm{w}$ postać obserwatora i zarazem uczestnika zdarzeń (ang. first-person perspective $)^{21}$. Jak łatwo się domyślić, wyrażenia deiktyczne mają niebagatelne znaczenie dla zrozumienia procesu komunikacji, w tym również interesującej nas komunikacji literackiej, kiedy bowiem percypujemy tekst językowy (wiersz, powieść, dramat itd.), ustalić musimy nie tylko, kto do kogo mówi, co i w jakiej sytuacji, ale również - jaki jest tego skutek ${ }^{22}$, a więc być w stanie „zrekonstruować zasady, które rządzą strukturą wypowiedzi"23, bez których nie można zrozumieć rzeczywistego sensu zdań. Tymczasem wyrażenia deiktyczne (deiksy) mają charakter kontekstowy i relacyjny, „za każdym razem [...] dostosowują się do centrum deiktycznego"24. Peter Stockwell wyróżnia więc sześć typów deiksy literackiej, z których interesować mnie będą trzy: przestrzenna, czasowa, a szczególnie percepcyjna - odnosząca się do zaangażowanych w teksto-

${ }^{20}$ P. Stockwell, dz. cyt., s. 70. Szerzej pisze o tej kwestii m.in. McIntyre, dz. cyt., s. 99-121. Deiktyczna analiza wiersza znajduje się na stronach 65-68. Zob. także krytykę koncepcji Stocwella autorstwa Reuvena Tsura w rozdziale Deixis In Literature. What Isn't Cognitive Poetics? Tegoż, Toward a Theory of Cognitive Poetics, Brighton \& Portland 2008, s. 595 i n.

${ }^{21}$ B. Prus, Placówka, oprac. T. Żabski, Wrocław-Warszawa-Kraków-Gdańsk-Łódź 1987, s. 3. Por. interesujące uwagi na temat relacji między narracją i empatią w pracy M. Koza, Czy można wspótczuć literaturze? Kognitywne aspekty roli empatii $w$ procesie lektury, [w:] Emocje, ekspresja, poetyka - przeglad zagadnień, red. D. Saniewska, Kraków 2013, s. 29-36.

${ }^{22}$ M. Głowiński, Komunikacja literacka jako sfera napięć, [w:] tegoż, Style odbioru. Szkice o komunikacji literackiej, Kraków 1977, s. 7-8.

${ }^{23}$ Tamże, s. 10.

${ }^{24}$ P. Stockwell, dz. cyt., s. 66. Por. V. Evans, M. Green, Cognitive Linguistics. An Introduction, Edinburgh 2006, s. 197. 
wą sytuację komunikacyjną uczestników ${ }^{25}$. Jak bowiem zauważa autor Poetyki kognitywnej: „postaci w scenariuszu [tekście - A.S.M.] są społecznie zakotwiczone nie absolutnie, lecz względem siebie nawzajem"26, czyli przybierane przez czytelnika centrum deiktyczne zmienia się w zależności do interakcyjnych poczynań tekstowych aktantów. Gdy więc czytamy w polskim tłumaczeniu jednej z popularnych pieśni:

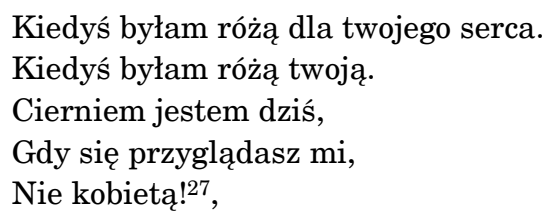

nie tylko bez trudu identyfikujemy nadawcę i sytuację komunikacyjną, ale również (odwołuję się tu do całości tekstu) zrekonstruować możemy szeroki kontekst, tło emocjonalne i „historyczne” monologu, a nawet wyprowadzić pewne wnioski co do adresata. Centrum deiktycznym jest tu porzucona przez kochanka kobieta artykułująca swój żal po stracie $\mathrm{w}$ formie pieśni-lirycznego wyznania. Ten swoisty planctus ustanawia wyraźne relacje przestrzenne, czasowe i osobowe, które mogą być również wyrażone w inny sposób - choćby z pomocą tekstu pobocznego lub informacji zawartych w wypowiedzi powieściowego narratora.

\section{Barthes: miłość - nieobecność - komunikacja}

Wszaki̇e uczucia miłosne $i$ listy sq zawsze $w$ intencji $i$ treści podobne

- Stanisław Wasylewski ${ }^{28}$

Są jednak i takie teksty, w których identyfikacja ról nadawczo-odbiorczych i powiązanych z nimi centrów deiktycznych nie jest bynajmniej tak oczywista, jak w przykładzie powyższym. Jednym z nich jest bezsprzecznie utwór List, a wtaściwie dwa... z repertuaru Roberta Kasprzyckiego - krakowskiego poety, pieśniarza, felietonisty i twórcy tekstów ka-

${ }^{25}$ P. Stockwell, dz. cyt., s. 68. Nie jest to oczywiście jedyny możliwy podział. Dla przykładu McIntyre wymienia w swej pracy pięć typów deiksy: przestrzenną, czasową, osobową, społeczną i empatyczną (s. 94-99).

${ }^{26}$ P. Stockwell, dz. cyt., s. 66.

27 Opracowanie bałkańskiej pieśni folkowej (Ružica si bila). Polskie tłumaczenie pieśni pochodzi z płyty Kayah i Bregović, BMG 1999.

28 S. Wasylewski, O miłości romantycznej, Warszawa 1958, s. 14. 
baretowych. Utwór ten wykonywany przez autora jako ballada śpiewana przy wtórze gitary posiada niezwykle interesującą formę. Poeta nie tylko bowiem łączy dwie role nadawcze - pozwolę sobie określić je zaczerpniętymi z greki terminami: 1. poietyczną tj. związaną z kompozycją tekstu i 2. aojdyczną - wykonawczą ${ }^{29}$, ale również, z racji pierwszoosobowego charakteru poetyckiego „monologu” 30 może być jednocześnie postrzegany jako twórca-wykonawca i podmiot tekstowy. Już więc „na wstępie” dystrybucja poziomów komunikacji jest do pewnego stopnia złożona, tym bardziej, że - jak pamiętamy - piosenka owa mianowana jest przez autora listem (co wzbogaca kontekst interpretacyjny schematu komunikacyjnego o dodatkowy, różny od aojdyczno-autorskiego, poziom: adresata listu). Nim więc przejdziemy do bardziej szczegółowych rozważań, przytaczam całość tekstu. By jednak nie sugerować niczego, pomijam odautorskie cudzysłowy wprowadzające demarkujące rozróżnienie pomiędzy mowę nadawcy i odbiorcy (co, jak mniemam, pozostaje w zgodzie z faktycznym sposobem istnienia tekstu, który w swym prymarnym kształcie ma postać nagrania fonograficznego. Dla lepszego zrozumienia mojej intencji odsyłam więc do wersji audio, której zapis jest tylko nieudolnym odwzorowaniem $)^{31}$ :

Dziś przyszedł list, a właściwie dwa - w jednej zamknięte kopercie myślałem już, że to jakiś żart, później zadrżały mi ręce:

Jak czujesz się, czy ci czegoś brak i pozdrowienia serdeczne, zmieniłem się, wszystko jest nie tak, napisz więc do mnie koniecznie...

Kiedyś byliśmy razem, lecz tego nie można odwrócić precyzyjnie ciął lancet dwoje serc wspólne kłótnie plany noce nici sny precyzyjnie ciął lancet każdą rzecz, która miała złączyć słowa ,ja” i „ty”

Niczego już nie potrzeba mi, prócz kilku twarzy znajomych.

Czasami zbyt często mi się śnisz, lecz snów nie można przegonić skrzywieniem warg, czy zerwaniem strun, gdy ktoś przypomni melodię upartych fraz, które drążą mózg, nie pozwalając zapomnieć.

Odnajdziesz mnie na rozstajach dróg. Sprawcy podobno wracają po śladach swych, a gdy wrócisz tu, gdzie czas w zdumieniu przystanął to nie mów nic. Już nie ty, nie ja. Inna już rzeka tam płynie.

Przejdź obok mnie, nie patrz w moją twarz, niech się w ciemnościach rozpłynę.

${ }^{29}$ Dokonuję tego rozróżnienia z uwagi na fakt częstej w poezji śpiewanej nieprzystawalności autora tekstu i jego wykonawcy.

${ }^{30} \mathrm{~W}$ dalszej partii tekstu wyjaśnię, skąd cudzysłów.

31 Problem podejmuję w dalszej partii tekstu. 
Więc nawet list, a właściwie dwa, ach twe małżeńskie skrupuły, nie zmienił nic. Zima nadal trwa z tej strony mojej półkuli.

Mam nowy dom, zbudowałem go na podwalinach z popiołu.

Palę twój list, popiół zgarniam w kąt, nim wiatr go strąci ze stołu ${ }^{32}$.

Po przeczytaniu powyższych wersów z pewnością wielu czytelników uzna, że jest to spójna, pozbawiona luk wypowiedź jednego podmiotu, która to wprowadza $\mathrm{w}$ trzecim wersie cudzy głos w mowie niezależnej. Czy jednak tak jest $\mathrm{w}$ istocie? Czy słuchając piosenki w wersji fonograficznej, możemy rzeczywiście mieć taką pewność? W końcu - czy tekst sam w sobie „zmusza” nas do przyjęcia takiej a nie innej perspektywy, czy determinuje swój kształt raczej niż pozostawia go naszej percepcyjnej (intencjonalnej) aktywności?

Zauważyliśmy już wcześniej, że komunikacja miłosna ma specyficzną, odmienną od innych gier językowych naturę. Sytuacja wykonania zdaje się implikować jedną tylko instancję nadawczą, pamiętać należy, iż - jak zauważa w swojej pracy Barthes - komunikacja w formie listu miłosnego zawiera $\mathrm{w}$ sobie przede wszystkim domyślną kategorię nieobecności, ta zaś istnieje tylko w jednej postaci: nieobecnego innego. „Miłosna nieobecność - twierdzi autor $S / Z$ - ma jeden zaledwie kierunek i może być wypowiedziana tylko od strony tego, kto pozostaje - a nie tego, kto wyjeżdża"33. Możliwym sposobem usunięcia braku innego jest komunikowanie poprzez pisanie listów. Jak bowiem zauważa Katarzyna Młynek:

Słowo komunikacja pochodzi od łacińskiego czasownika communicare, co oznacza „uczynić wspólnym, połączyć lub naradzić się”, od rzeczownika communio oznaczającego „wspólność, zespolenie i poczucie łączności”; a także przymiotnika communis znaczącego „wspólny, powszechny lub ogólny”34.

Otóż, miłosna korespondencja nie jest (referuję tu wciąż obserwacje Barthesa) w istocie „tylko” komunikacją, ale raczej nawiązaniem relacji, zwróceniem się ku nieobecnemu, wręcz próbą „sprowadzenia” go ${ }^{35}$ : „kiedy piszesz do kogoś, to dla niego, a nie dla siebie. [...] List miłosny, będąc pragnieniem, oczekuje odpowiedzi; podskórnie nakazuje innemu, by odpowiedział" 36 . Jest więc, zgodnie z etymologią pojęcia komunikacji, za-

${ }^{32}$ R. Kasprzycki, List a właściwie dwa ..., <http://www.kasprzycki.pl>, dostęp: 27.10. 2013.

${ }^{33}$ R. Barthes, Fragmenty dyskursu miłosnego..., s. 23.

${ }^{34} \mathrm{~K}$. Młynek, $O$ trzech zagadnieniach zwiazanych ze zjawiskiem komunikacji, [w:] Komunikologia. Teoria i praktyka komunikacji, red. E. Kulczycki, M. Wendland, Poznań 2012, s. 242.

${ }^{35}$ R. Barthes, Fragmenty dyskursu miłosnego..., s. 248-249.

36 Tamże. 
proszeniem do wspólnotowości, ale również - na co zwraca uwagę Młynek - rodzajem międzypodmiotowego agonu, jednocześnie alienacją (Sartre) i dialogiem (Buber, Levinas) ${ }^{37}$. Jak zobaczymy, owa paradoksalność i antytetyczność znajduje odbicie również w strukturze utworu Kasprzyckiego.

\section{Medium a sens wiersza}

Jak sygnalizowałem, w zamieszczonej wyżej wersji tekstu pominąłem odautorskie cudzysłowy, by nie sugerować jednej interpretacji i oddać w jakimś stopniu warunki percepcji fonograficznej, a zatem wyłącznie słuchowej. Poza tym drobnym zabiegiem kształt wersyfikacyjny utworu pozostawiam bez zmian (za wersją umieszczoną na stronie internetowej autora), mimo iż w mojej opinii jest on niezgodny tak ze standardami notacji wierszowej (uzus nakazuje zapisywać tekst piosenki krótkimi wersami) ${ }^{38}$, jak też narzuca odbiorcy oczywiste ograniczenia (względem nagrania) w materii semantyki prozodyjnej. Przykładowo - w zapisie powyższym stoi:

Niczego już nie potrzeba mi, prócz kilku twarzy znajomych.

Czasami zbyt często mi się śnisz,

podczas gdy wykonanie głosowe umożliwia odczytanie:

Niczego już nie potrzeba mi, prócz kilku twarzy znajomych.

Czasami zbyt. Często mi się śnisz

$\mathrm{Z}$ podobnym zjawiskiem mamy też do czynienia $\mathrm{w}$ ostatniej strofie, gdzie poszczególne segmenty wersów (nazwijmy je umownie „członami pośredniówkowymi”) mogą być przypisywane bądź to do danego wersu, bądź też jego następnika - tak, jak to ilustruje poniższy fragment:

Zima nadal trwa z tej strony mojej półkuli.

Mam nowy dom, zbudowałem go na podwalinach z popiołu.

Palę twój list, popiół zgarniam w kąt, nim wiatr go strąci ze stołu

oraz w zapisie ukazującym inną łączliwość składniową wynikającą z fonograficznego charakteru prototypowego kontaktu z tekstem:

${ }^{37}$ K. Młynek, dz. cyt., s. 243.

${ }^{38} \mathrm{Nie}$ znalazłem opracowania bezpośrednio odnoszącego się do podnoszonej kwestii, niemniej jest to chyba rzecz powszechnie znana. $\mathrm{Z}$ dostępnych pozycji wiele uwag potwierdzających tę tezę zawiera praca Lucylli Pszczołowskiej Wiersz polski. Zarys historyczny, Wrocław 2002, passim. 
Zima nadal trwa. Z tej strony mojej półkuli

Mam nowy dom, zbudowałem go na podwalinach z popiołu palę twój list.

Te drobne z pozoru rozbieżności, z jakimi może mieć do czynienia słuchacz, a które nie dają się zanotować w zapisie typograficznym, mają ogromne znaczenie dla rozszerzenia palety możliwych konceptualizacji, szczególnie zaś, że owa wieloznaczność współgra z ogólną semantyką tekstu.

\title{
Deiktyczny "tryb" lektury jako odpowiedź na potencjalną wieloznaczność tekstu
}

\author{
Kto to mówi? \\ - Roland Barthes ${ }^{39}$
}

Rozważając postawiony przez autora Mitologii problem nieobecności, musimy zapytać, kto w tym przypadku jest owym nieobecnym: ten, kto mówi (właśc. śpiewa), czy też ten, kto wysyła list? A może jeszcze ktoś inny (kto)? Zdaje się, że wszystkie odpowiedzi są jeśli nie równouprawnione, to chociaż dopuszczalne. Tytuł utworu mówi wprost o dwóch listach zamkniętych „w jednej kopercie” - co można rozumieć na przynajmniej dwa sposoby: 1. jako wewnętrzną dialogiczność wypowiedzi nadawcy oraz 2. jako Barthesowskie wezwanie do odpowiedzi, otwarcie komunikacji na głos nieobecnego innego (adresata), a więc dialogiczność per se (międzypodmiotową). W takiej sytuacji drugim listem byłaby nie mniej, nie więcej sama wypowiedź odbiorcy, wejście w sytuację dialogiczną. Potwierdzać tę obserwację zdaje się zawarte $\mathrm{w}$ tytule (paradoksalne) sformułowanie: „[...] a właściwie dwa”. Cóż bowiem miałoby owo „właściwie” oznaczać? Otóż: albo dwa niekonsensualne listy, albo wewnętrzną niespójność w ramach jednego listu, albo wreszcie - intencję zaproszenia do komunikacji. Przecież pierwsze linijki cytowanego w utworze listu należałoby chyba czytać tak:

„Jak czujesz się, czy ci czegoś brak?” i „pozdrowienia serdeczne”,

„Zmieniłam się, wszystko jest nie tak, napisz więc do mnie koniecznie...”

Jest to przy tym jedno z niewielu miejsc pozornie pewnych, to znaczy takich, gdzie dystrybucja podmiotu nie pozostawia (jak się zdaje) najs. 247.

${ }^{39}$ R. Barthes, Śmierć autora, przeł. M.P. Markowski, „Teksty Drugie” 1999, nr 1-2, 
mniejszych wątpliwości (jej znakiem jest żeńska końcówka fleksyjna czasownika $)^{40}$. Jeśli jednak zdamy sobie sprawę, iż wykonanie głosowe różni się $\mathrm{w}$ tym miejscu, bowiem zamiast formy żeńskiej pojawia się męska („zmieniłem się"), i ta prosta konstatacja traci na pewności. Zaznaczam, że nie chcę rozwiązywać istniejącego tu problemu ról nadawczych i odbiorczych. Nie taka jest moja intencja. Chciałem raczej wskazać na istniejącą w strukturze tekstu problematyczność ich jednoznacznego zaklasyfikowania. Z tego napięcia pomiędzy różnymi możliwymi odczytaniami rodzi się bowiem wieloznaczność, swoista „niestabilność semantyczna” sensu, która to stanowi o atrakcyjności tekstu. Dalsze rozważania stanowią więc właśnie próbę omówienia tej problematyzacji z wykorzystaniem koncepcji przesunięcia deiktycznego, nie zaś - usunięcia jej.

W moim przekonaniu, percypując niniejszy utwór, można rzecz jasna ograniczyć się do jednego („potocznego”) odczytania, czyli umieścić deiktyczne centrum po stronie podmiotu-wykonawcy na całej właściwie przestrzeni tekstu. Niemniej jestem przekonany, że takie odczytanie zubaża tekst, ogranicza jego semantyczną nośność. Ponieważ jednak struktura nigdy nie determinuje absolutnie wykonywanych przez czytelnika przesunięć na polu deiksy ${ }^{41}$, wszystko pozostaje w gestii jego wrażliwości oraz kompetencji empatycznych i komunikacyjnych. Niemniej, jak zauważa piszący o podmiocie literackim Władysław Panas:

Przejrzysty model komunikacji [tu] nie wystarcza, ponieważ $-\mathrm{z}$ interesującego nas w tej chwili punktu widzenia - podmiot sprowadzony jest do roli nadawcy bądź odbiorcy. [...] [Gdy tymczasem - A.S.M.] [a]kt komunikacji ma charakter dynamiczny $^{42}$.

Co więcej, ma on nie tylko charakter dynamiczny, ale również kontekstowy, czyli jest jako taki niedookreślony. Wykorzystując zjawisko deiktycznego przesunięcia dokonywanego podczas lektury tekstu, możemy wyjść poza prostą opozycję, niejako spojrzeć na zachodzącą w utworze komunikację z kilku różnych stron (ujęć), a zatem te same zdania będą dla nas znaczyć więcej (co innego). Nie mam rzecz jasna na myśli czysto technicznego rozróżnienia, ale fakt, iż ten tekst stwarza możliwość wyjścia poza punktowy ogląd, a poprzez wynikające $\mathrm{z}$ niedookreśloności i przemienności centrów deiktycznych transpozycje sensu, pozwala przyjmować różne perspektywy interpretacyjne, a więc nie tylko pojmować

${ }^{40}$ Formy gramatyczne wskazujące na męski podmiot znajdujemy odpowiednio w pierwszej (wers 2) i ostatniej (drugi wers od końca) strofie.

${ }^{41}$ Por. P. Stockwell, dz. cyt., s. 69.

${ }^{42}$ W. Panas, $Z$ zagadnień semiotyki podmiotu, [w:] Autor - podmiot literacki - bohater, pod red. A. Martuszewskiej i J. Sławińskiego, Wrocław 1983, s. 32. 
świat tekstu z odmiennych pozycji, ale także empatycznie wczuwać się w odczucia postaci. Gdy więc przykładowo czytamy/słyszymy frazę:

[...] często mi się śnisz, lecz snów nie można przegonić skrzywieniem warg,

niejako odruchowo utożsamiamy się albo z podmiotem-wykonawcą, albo autorem listu, drugiego uczestnika komunikacji usuwamy zaś poza deiktyczne centrum (nie patrzymy na świat ,jego oczami”). W momencie, gdy uświadomimy sobie, że nie musimy wcale wybierać pomiędzy nadawcą i adresatem, ale tylko zmieniać punkty widzenia, możliwe staje się nie tylko lepsze zrozumienie, ale w ogóle wykreowanie biograficznej sytuacji kontekstowej, jakiej nie znajdujemy przy pierwszej lekturze. O ile zakładając jednoznaczność komunikacji, czynimy podmiot-odbiorcę tworem pozbawionym zasadniczo biografii, po prostu lektorem odczytującym cudze słowo, o tyle przemieszczanie punktu odniesienia pozwala wzbogacić (skomplikować) emocjonalno-biograficzne podłoże lirycznej sytuacji dialogu. Bo czyż nie zmienia istotnie naszych odczuć fakt, że stwierdzenie poniższe:

Niczego już nie potrzeba mi, prócz kilku twarzy znajomych.

Czasami zbyt. Często mi się śnisz, lecz snów nie można przegonić skrzywieniem warg,

pada z ust lirycznego bohatera, gdy przed chwilą skłonni byliśmy uznać je raczej za fragment odczytanego listu? Dalej: o czyje małżeńskie skrupuły idzie - zamężnej kobiety, która jednak „często” śni o dawnym kochanku? A może to samotny, opuszczony mężczyzna? Oba odczytania istotnie wpływają przecież na nasze wyobrażenie łączącej bohaterów relacji, inaczej ustanawiają ich względem siebie. Te i inne zawiłości czynią prosty z pozoru tekst ciekawym, angażują odbiorcę w złożony sposób, zmuszają do ciągłej refleksji. Jeśli bowiem to kobieta zasypia i śni o niegdysiejszym partnerze, mamy do czynienia z niewiernością, gdy zaś mężczyzna $-\mathrm{z}$ obojętnością po jednej stronie. Zmiana centrum deiktycznego sprawia więc, że każde właściwie zdanie może być oświetlone inaczej, a zatem nabrać innego sensu.

\section{Jedna litera}

W jednym ze swych najbardziej znanych esejów, La Différance, Jacques Derrida napisał:

Będę więc mówić o jednej literze. Pierwszej, jeśli wierzyć alfabetowi i większości spekulacji, które zapuściły się w tym kierunku. Będę więc mówić o literze $a$, o tej 
literze pierwszej, którą wydało się konieczne wprowadzić tu i tam do pisowni wyrazu différence ${ }^{43}$.

Jak pamiętamy, ta drobna zmiana uczyniona przez filozofia w pisowni jednego z francuskich leksemów stała się zaczynem dla bardzo subtelnych rozważań filozoficznych o naturze znaku i pisma. Ja również chciałbym poruszyć kwestię znaczenia jednej litery, choć oczywiście będzie to obserwacja zupełnie innej wagi i rodzaju. Powróćmy więc do sygnalizowanej wcześniej uwagi na temat drobnej różnicy pomiędzy zamieszczonym na stronie internetowej tekstem piosenki i jego wykonaniem - mam na myśli opozycję $a$ i $e$ we fragmencie „zmieniła / em się, wszystko jest nie tak". W jednej wersji wskazuje ona na żeńskiego nadawcę listu, gdy zaś $\mathrm{w}$ miejsce litery $a$ podstawimy (jak czyni to Kasprzycki, śpiewając) $e$, autorem niniejszych słów staje się (paradoksalnie!) mężczyzna. Jak to (z)rozumieć? Do kogo należą te słowa? Skąd wzięły się w cudzym liście? Ta $\mathrm{z}$ pozoru banalna kwestia ma $\mathrm{w}$ istocie ogromne znaczenie, kiedy stawką jest interpretacja. Akceptując tę zmianę jako różnicę znaczącą, zmuszeni jesteśmy do rozszerzenia zakresu możliwych interpretacji tytułu (wyjściowej sytuacji lirycznej). W takim wypadku ów „drugi list” byłby więc nie czym innym, jak listem odesłanym przez adresata do nadawcy. Mężczyźnie „drżą ręce” nie dlatego, że otrzymuje wieści od (dawnej) ukochanej, tj. ze wzruszenia, ale dlatego, że trzyma w ręku kawałek papieru zapisany niegdyś własnym pismem oraz drugi - komentarz. Oto więc pisze on (w nadziei na pozytywną odpowiedź): „Jak czujesz się, czy ci czegoś brak i pozdrowienia serdeczne, / zmieniłem się, wszystko jest nie tak, napisz więc do mnie koniecznie", ale otrzymuje odpowiedź negatywną i jednoznaczną w swej wymowności: „Kiedyś byliśmy razem, lecz tego nie można odwrócić" - odpisuje kobieta odsyłająca nawet list jako znak obecności, którego nie chce zatrzymać. Oczywiście i ta wersja interpretacji wpływa na rozumienie każdej właściwie frazy tekstu, często powodując coś w rodzaju tarcia pomiędzy niespójnymi, lub też nie do końca spójny$\mathrm{mi}$, semantycznie fragmentami poszczególnych wypowiedzi.

Choć zdaje mi się, że ostatnia propozycja jest interpretacyjnie najciekawsza, nie chcę odcinać wcześniejszych. Tym, co dla mnie istotne, jest samo „przeniesienie” deiktycznego centrum, jakie dokonało się pomiędzy dwoma tekstami-interpretacjami: o ile wcześniej właściwie cały utwór był wypowiedzią mężczyzny sprowokowaną listem kobiety, o tyle w wersji ostatniej dochodzimy do sytuacji będącej odwróceniem układu „na wejściu".

43 J. Derrida, Różnia, [w:] tegoż, Marginesy filozofii, przeł. J. Margasiński, Warszawa 2002, s. 30 . 


\title{
Wnioski: od tekstu do metody interpretacji
}

\begin{abstract}
[...] potykam się, gmatwam. Zawsze w końcu pozostanie margines niepewności; to rozróżnienie nie będzie źródtem ostatecznych klasyfikacji, paradygmat zazgrzyta, sens będzie niestaty, odwotywalny, odwracalny, a dyskurs niepelny.
\end{abstract}

- Roland Barthes ${ }^{44}$

Gdy przywoływałem cytat mówiący, iż listy i miłość są „w treści i intencji" podobne, gdy pisałem, że dyskurs miłosny jest komunikacyjnie paradoksalny i komunikowalny tylko do pewnego stopnia, miałem przede wszystkim na myśli to, że znaczenia, jakie te gry językowe niosą, są $\mathrm{w}$ istocie niezdeterminowane (czy raczej są nieustannie determinowane przez różne, zmieniające się, zachodzące na siebie konteksty i użycia). Celowo więc nie starałem się ani dać wyczerpującej interpretacji, ani też wprowadzić jakiegoś pomiędzy nimi rozgraniczenia. Z rozmysłem również korzystałem z różnych możliwości, których „prawomyślne” odczytanie tekstu Kasprzyckiego nie daje. Starałem się raczej mieszać różne porządki, formy podawcze (zapis, nagranie), znajdywać miejsca niejasne, w których sens jest niepewny, zaciemniony, wieloznaczny - czyli po prostu: szukałem adekwatnej formy lektury tego tekstu (a przynajmniej takiej jego postaci, jaką sobie w procesie interakcji z nim wytworzyłem). W moim bowiem odczuciu taki właśnie sposób lektury jest w przypadku tego wiersza-piosenki najbardziej stosowny, maksymalnie zgodny z tak zwaną „intencją tekstu”. Jego wewnętrzna strukturalna deiktyczność - kontekstualna zależność i otwartość - która (nie wiem, czy z woli autora, czy też poza nią) stanowić winna nie tylko interpretacyjną poszlakę, ale wręcz istotę interpretacji. Określenie lektura deikty c z n a stanowi rzecz jasna pewnego typu metaforę - mianowicie metaforę procesu, który podąża za tekstem tak, jak on sam w czasie lektury się zmienia.

Pisząc ten tekst, stawiałem przed sobą tylko jeden cel: opisanie jego semantyki zmieniającej się zależnie od przyjętego centrum dekitycznego, pewnej pojedynczej poetyki odczytania wynikającej z podszytej ciekawością wielokrotnej lektury, próby przyjęcia różnych zakorzenionych $\mathrm{w}$ tekstowym świecie punktów oglądu. W pewnym momencie zdałem sobie jednak sprawę, że nie tylko czytam tekst, ale zaczynam go zmieniać, że każde kolejne odczytanie (niedoczytanie?) przestaje mnie satysfakcjonować - że cały czas jest coś więcej i więcej... Coś, co chciałbym, aby mi on o sobie powiedział. Kolejne obserwacje nakładały się na siebie, two-

${ }^{44}$ R. Barthes, Przyjemność tekstu, przeł. A. Lewańska, Warszawa 1997, s. 8. 
rząc mozaikę, czy wręcz kłącze, które nie miało ani początku, ani końca. W końcu, muszę przyznać, zgubiłem się w tekście. Nie wiem już z całą pewnością, kto, co i do kogo w danym miejscu mówi. Tak jak miłość w wierszu Blake'a, niedające się wypowiedzieć pragnienie, w istocie jest wypowiedzeniem, tak tekst wiersza (choć nieuchwytny) domaga się wciąż kolejnych posunięć interpretacyjnych. O ile więc - jak sugerowałem dyskurs miłosny uznać wypada z pewnych względów za antytezę komunikacji literackiej, o tyle zdać się on może jednak modelem interpretacji (jako działania, które dąży do egocentrycznego ustalenia sensu, nie zaś do komunikatywności i powszechności). Nie wiem, czy zaproponowany tu model czytania sprawdzić się może w lekturze jakiegokolwiek innego utworu. Istotą jego jest raczej to, iż oświetla ten właśnie tekst, podąża za jego wieloznacznością. Wychodząc od tematu (miłości jako sytuacji komunikacyjnej), stara się nie tylko oddać jego ducha, być „blisko tekstu”, ale również podejmuje interpretacyjny dialog łączący wiele płaszczyzn i aspektów interpretacji. Ta zaś nie jest tu od-czytaniem, ale raczej ciągłym w-czytywaniem się, do-czytywaniem. Nie szukam „ostatecznego” sensu, lecz - pamiętając słowa Rolanda Barthesa mówiącego: „musicie dobrze interpretować, co oznacza koniec końców umniejszać"45 - starałem się raczej odkrywać coraz to nowe jego pokłady, odruchowo kolekcjonować znaczenia ${ }^{46}$, a jednocześnie nie zamykać się na potencjalne niedomknięcie moich poczynań jako czytelnika, czyli (niczym narrator Czułego barbarzyńcy Bohumila Hrabala) „zostawiam tekst jak rozkopaną ulicę"47. "Czytelnik - napisze gdzie indziej francuski badacz - [jest kimś A.S.M.], kto zbiera w tym samym polu wszystkie ślady, z których powstał tekst"48.

${ }^{45}$ R. Barthes, Fragmenty dyskursu miłosnego..., s. 236.

46 Por. S. Jasionowicz, dz. cyt., s. 79.

${ }^{47}$ B. Hrabal, Czuły barbarzyńca. Teksty pedagogiczne, przekład A. Kaczorowski, wyd. drugie przejrzane, Warszawa 2011, s. 7.

${ }^{48}$ R. Barthes, Śmierć autora..., s. 251. 